\title{
PELAKSANAAN ASESMEN PERKEMBANGAN ANAK DALAM PEMBELAJARAN DARING
}

\section{IMPLEMENTATION OF CHILD DEVELOPMENT ASSESSMENT OF ONLINE LEARNING}

\author{
1) Siti Fadillah, ${ }^{2)}$ Sri Wahyuni, ${ }^{3)}$ Azlin Atika Putri \\ 1,2,3 Fakultas Keguruan dan Ilmu Pendidikan, Universitas Lancang Kuning \\ *Email: sitifadillah@unilak.ac.id
}

\begin{abstract}
ABSTRAK
Asesmen perkembangan anak usia dini adalah sebuah proses penilaian yang komprehensif dan melibatkan anggota tim untuk mengumpulkan dan mengevaluasi informasi mengenai performa anak, sesuai dengan tahap perkembangan yang sedang dilaluinya. Mitra dalam IbM ini adalah Guru dan para orang tua wali murid di TK Dayyinah Kids 2 Rumbai yang mendampingi anak dalam masa belajar dirumah atau daring selama masa pandemi covi - 19. Permasalahan yang ditemukan yaitu Guru dan orang tua belum memahami tentang Pelaksanaan asesmen perkembangan anak dalam pembelajaran daring Adapun solusi yang ditawarkan oleh tim pengusul IbM adalah sosialisai pelaksanaan asesmen perkembangan anak dalam pembelajaran daring. Setelah kegiatan IbM ini diharapkan Guru dan para orang tua mampu melaksanakan asesmen perkembangan anak dengan baik dan tepat. Adapun hasil dari pelaksanaan pengabdian ini yaitu meningkatnya pemahaman orang tua dan guru di TK Dayyinah Kids mengenai pelaksanaan asesmen perkembangan anak selama pembelajaran daring. pemahaman tentang asesmen perkembangan anak dalam pembelajaranb daring bagi guru dan orang tua setelah dilaksanakan kegiatan sosialisai mengalami peningkatan signifikan dengan kenaikan persentase sebesar 33.13\%.
\end{abstract}

Kata Kunci : Asesmen, Perkembangan, Pembelajaran Daring, Anak Usia Dini

\section{ABSTRACT}

Early childhood development assessment is a comprehensive assessment process and involves team members to collect and evaluate information about the child's performance, according to the stage of development he is going through. Partners in IbM are teachers and parents of students at Dayyinah Kids 2 Rumbai Kindergarten who accompany children during their learning at home or online during the COVID-19 pandemic. The problems found are that teachers and parents do not understand the implementation of child development assessments in online learning The solution offered by the IbM proposing team is the socialization of the implementation of the assessment of child development in online learning. After this IbM activity, it is hoped that teachers and parents will be able to carry out child development assessments properly and appropriately. The results of the implementation of this service are increasing the understanding of parents and teachers at Dayyinah Kids Kindergarten regarding the implementation of child development assessments during online learning. understanding of the assessment of child development in online learning for teachers and parents after the socialization activities have been carried out has increased significantly with a percentage increase of 33.13\%.

Diterima : 20-01-2021 Disetujui : 1-03-2021 Dipublikasikan: 30-06-2021 


\section{PENDAHULUAN}

Pandemi COVID-19 memberikan dampak pada banyak pihak, kondisi ini sudah merambah pada dunia pendidikan, pemerintah pusat sampai pada tingkat daerah memberikan kebijakan untuk meliburkan seluruh lembaga pendidikan. Berdasarkan surat edaran nomor 36962/MPK.A/HK/2020 yang menyatakan agar seluruh kegiatan belajar dan mengajar baik disekolah mulai seklolah PAUD maupun perguruan tinggi dilaksanakan dirumah secara online atau dengan menggunakan metode daring.

Kegiatan belajar mengajar di tanah air berubah kala virus corona masuk ke Indonesia. Pemangku kebijakan negeri ini memutuskan kegiatan tersebut dilakukan di rumah secara online atau dengan model dalam jaringan (daring). Ini pekan ketiga pembelajaran dilaksanakan secara daring, tentu kreativitas para guru ditekankan agar para anak nyaman belajar. Meskipun daring, pembelajaran anak usia dini harus mengedepankan enam aspek perkembangan anak usia dini yakni Nilai agama dan moral, Fisik-Motorik, Kognitif, Bahasa, Sosial-Emosional, dan Seni. Oleh sebab itu guru dan orang tua harus memiliki konsep yang jelas dalam pembelajaran daring serta cara penilaian nya. Brewer (2007: 202) mendefinisikan asesmen sebagai pengumpulan dan pengevaluasian informasi mengenai performa individu, kualitas suatu program, atau keefektifan suatu kegiatan.

Permasalahan yang ditemukan dilapangan yaitu belum adanya sosialisai terhadap orang tua mengenai bagaimana pelaksanaan evaluasi atau asesmen pembelajaran daring bagi anak usia dini khususnya di TK dayyinag Kids 2 Rumbai Kota Pekanbaru. Adapun solusi yang ditawarkan pada oleh tim pengusul IbM adalah sosialisai Sosialisasi Pelaksanaan Asesmen Perkembangan Anak Dalam Pembelajaran Daring

\section{METODE}

1. Solusi yang di Tawarkan.

Adapun solusi yang diberikan oleh Tim pengusul program IbM adalah

a. Mensosialisasikan kepada orang tua mengenai enam aspek perkembangan anak.

b. Sosialisasi bagaimana asesmen atau penilaian perkembangan anak usia dini dalam pembelajaran daring bisa dilakukan oleh orang tua dirumah dan dievaluasi oleh guru.

c. Melatih orang tua untuk dapat menggunakan penilaian untuk melihat kemajuan perkembangan anak selama pembelajaran daring.

d. Setelah adanya IbM ini diharapkan guru- guru dan orang tua mampu melaksanakan penilaian dan membuat laporan kemajuan perkembangan anak dengan baik dengan mencakup enam aspek perkembangan anak usia dini khususnya di TK Dayyinah Kids 2 Rumbai Kota Pekanbaru.

\section{Prosedur Kerja}

Prosedur yang dilakukan dalam kegiatan ini terdiri dari beberapa rangkaian kegiatan, mulai dari melakukakan kegiatan analisis situasi berupa observasi lapangan dan interview sampai kepada pembuatan proposal dan laporan kegiatan pengabdian kepada masyarakat. Kemudian untuk pelaksanaan kegiatan sosialisasi 
menggunakan metode ceramah, diskusi atau tanya jawab. Prosedur yang dilakukan dalam kegiatan IbM ini terbagi 2 sesi yang dilakukan selama 1 hari

\section{HASIL DAN PEMBAHASAN}

Sosialisasi Pelaksanaan Asesmen Perkembangan Anak Dalam Pembelajaran Daring Pekanbaru telah dilakukan pada tanggal 8 Januari 2021. Berdasarkan angket yang disebarkan kepada peserta melalui google form, hasil dari respon angket menggambarkan bahwa sosialisi sangat bermanfaat bagi orangtua dan guru di TK Dayyinah Kids 2 Kota Pekanbaru. Hal itu tergambar dari peningkatan persentase pengetahuan orangtua dan guru tentang bagaimaimana mengelola pembelajaran yang baik secara online selama masa pandemi.

Kriteria penilaian masing-masing data pengetahuan orangtua dan guru terhadap pemahaman asesmen perkembangan anak dalam belajar daring mengacu pada batasan yang dikemukakan oleh Riduwan (2010: 15).

Berdasarkan hasil pengolahan
data, maka gambaran tentang
pengetahuan orangtua dan guru terhadap
asesmen perkembangan anak dalam
pembelajaran daring sebelum dan
sesudah dilakukan kegiatan sosialisai
secara online, secara umum berada pada
kategori cukup baik dengan rata-rata
43.44\%. Sedangkan setelah dilaksanakan
kegiatan sosialisao secara online
meningkat dan berada pada kategori baik
dengan rata-rata $76.56 \%$ Berdasarkan
data tersebut dapat disimpulkan bahwa
pemahaman tentang asesmen
perkembangan anak dalam
pembelajaranb daring bagi guru dan
orang tua setelah dilaksanakan kegiatan

sosialisai mengalami peningkatan signifikan dengan kenaikan persentase sebesar $33.13 \%$.

Berdasarkan data tersebut dapat di simpulkan bahwa orang tua sudah memiliki pengetahuan bagaimana mendampingi anak belajar di rumah serta bagaimana melihat perkembangan anak dengan melakukan asesmen secara pribadi di rumah, hal ini sejalan dengan pendapat Wijayani (2015) dan Qalbi (2020) anak merupakan home educandum. Yaitu anak merupakan mahluk pendidikan serta dapat dididik di rumah, oleh sebab itu pembelajaran daring membutuhkan pengetahuan orang tua dalam mendampingi serta melakukan penilaian agar pembelajaran daring dapat memberikan hasil sesuai dari tujuan pembelajaran yang di harapkan.

\section{SIMPULAN}

Sosialisasi pelaksaan asesmen perkembangan aud dalam pembelajaran daring sangat bermanfaat bagi guru dan orang tua serta anak didik dalam melaksanakan pembelajaran dan penilaian daring selama masa pandemic covid 19 . Terdapat peningkatan pengetahuan bagi orangtua dan guru tentang peranan orang tua dalam mendampingi anak belajar serta mengelola pelaksanaan penilaian pembelajaran yang efektif selama di rumah. Peningkatan ini menunjukkan bahwa kegiatan sosialisasi ini efektif dalam meningkatkan pengetahuan orangtua dan guru dalam melaksanakan asesmen pembelajaran selama pembelajaran daring dari rumah. 
Siti Fadillah, Sri Wahyuni, Azlin Atika Putri

\section{DAFTAR PUSTAKA}

Arsyad, Azhar. 2016. Media Pembelajaran. Jakarta: Raja Grafindo Persada.

Anugrahana, A. (2020). Hambatan, Solusi dan Harapan:

Pembelajaran Daring Selama Masa Pandemi Covid-19 Oleh Guru Sekolah Dasar. Scholaria: Jurnal Pendidikan Dan Kebudayaan, 10(3), 282-289. https://doi.org/10.24246/j.js.2020. v10.i3.p282-289

Bandi. 2006. Pembelajaran Anak Berkebutuhan Khusus (dalam setting Pendidikan Inklusi).Bandung: PT Refika Aditama.

Brewer, Jo Ann \&Miller, Patricia H., (2007), Introduction to Early Childhood

Education,Boston:Allyn And Bacon.

Damayanti, E., Hartika, A.S., Herawati, Lisna, Jannah R., Pratiwi, S.I., 2018, Menejemen Penilaian Pendidikan Anak Usia Dini pada Taman Kanak-Kanak Citra Samata Kabupaten Gowa, Indonesian Journal of Early Childhood Education, Vol I, No, I, hlm 13-24

Fridani, Lara, Sri Wulan, dan Sri Indah Pujiastuti. 2008. Penilaian Perkembangan Anak Usia Dini. Jakarta: Universitas Terbuka.

Hasri, Salfen. 2009. Sekolah Efektif dan Guru Efektif. Yogyakarta: Aditya Media Printing and Publising.

Qalbi, Z., Marlina, S., Febryan Putera, R., Hidayati, I., \& Eka Daryati, M. (2020). Pengaruh Permainan Maze Terhadap Kemampuan Bercerita di TK Negeri 1 Padang
Baru. Jurnal Pelita PAUD. https://doi.org/10.33222/pelitapau d.v4i2.1013

Riduwan. (2015). Dasar-Dasar Statistika.Bandung: Alfabeta.

Nawawi, Hadari. 1982. Organisasi Sekolah dan Pengelolaan Kelas Sebagai Lembaga Pendidikan. Jakarta : Gunung Agung.

Wijayani N A (2015). Manajemen PAUD Bermutu Konsep dan Praktik MMT di KB, RA/TK (Cetakan ke 1). Yogyakarta : Gava Media. 